\title{
The Prognostic Implications of Cystic Change in Clear Cell Renal Cell Carcinoma
}

Heae Surng Park • Eun-Jung Jung Jae Kyung Myung

Kyung Chul Moon ${ }^{1}$

Department of Pathology, Seoul National University College of Medicine; 'Kidney Research Institute, Medical Research Center, Seoul National University College of Medicine, Seoul, Korea

Received : August 20, 2009

Accepted : October 28, 2009

Corresponding Author Kyung Chul Moon, M.D., Ph.D.

Department of Pathology and Kidney Research Institute, Medical Research Center, Seoul National University College of Medicine, 28 Yeongeon-dong, Jongno-gu, Seoul 110-799, Korea

Tel: 02-2072-1767

Fax: 02-743-5530

E-mail: blue7270@snu.ac.kr

*This work was supported by grant No. 04-2009-007 from the SNUH Research Fund.
Background : Cystic renal cell carcinoma has been reported to have a good prognosis. However, previous studies included cases of multilocular cystic renal cell carcinoma, which has an excellent prognosis, and renal cell carcinoma with cystic necrosis, which has an adverse prognosis. Therefore, we analyzed the prognostic influence of cystic change in clear cell renal cell carcinoma after excluding those morphological features. Methods : We identified 225 patients with clear cell renal cell carcinoma who underwent nephrectomy between 2001 and 2003. The clinicopathologic features were compared with clinical outcomes. Results : Cystic change in clear cell renal cell carcinoma $(n=66)$ was significantly associated with younger patient age $(<55)$, smaller tumor size $(\leq 4 \mathrm{~cm})$, lower $\mathrm{pT}$ stage ( $\mathrm{pT} 1, \mathrm{~T} 2)$, M0 stage at initial diagnosis, lower tumor, node, and metastasis stage (I, II), and lower nuclear grade (1, 2). Patients with cystic change in clear cell renal cell carcinoma had significantly longer cancer-specific $(p=0.015)$ and progression-free survival $(p=0.004)$ than those without cystic change, by univariate analysis. Multivariate analysis revealed that cystic change significantly decreased the risk of cancer progression (risk ratio, $0.27 ; 95 \%$ confidence interval, 0.11 to 0.69 ). Conclusions : In patients with clear cell renal cell carcinoma, cystic change is a good independent predictor for survival.

Key Words : Carcinoma, renal cell; Prognosis; Pathology
The incidence of renal cancers has been increasing steadily with 57,760 new diagnoses and 12,980 deaths in the United States in 2009. ${ }^{1}$ Renal cell carcinoma (RCC) accounts for approximately $75 \%$ of these cases ${ }^{2}$ and clear cell type is the most common histologic variant. Clear cell RCC is associated with poorer cancer-specific survival (CSS) when compared with other subtypes. ${ }^{3}$ However, multilocular cystic renal cell carcinoma (MCRCC), a distinct subtype of clear cell RCC, has excellent prognosis with a 5 -year survival rate of $95 \%$ to $100 \% .^{4-6}$ Some studies reported that patients with cystic RCC, a category that includes MCRCC, unilocular cystic RCC, RCC with extensive cystic necrosis, and cystic RCC characterized by a unilocular cyst with one or a few isolated mural tumor nodules, had a better prognosis than patients with solid clear cell RCC. ${ }^{7-11}$ These studies should be clarified since RCC with cystic necrosis carries a significantly worse prognosis ${ }^{12}$ and MCRCC has an excellent outcome. Therefore, we performed a retrospective analysis to assess the prognostic implication of cystic change in clear cell RCC after excluding those confounding factors.

\section{MATERIALS AND METHODS}

\section{Patient selection}

We reviewed the pathology slides of patients treated with radical or partial nephrectomy for clear cell RCC between 2001 and 2003 at the Seoul National University Hospital. MCRCC or cases showing equivocal features for the diagnosis of typical clear cell RCC, such as papillary architecture and tumor cells with clear cytoplasm, reminiscent of clear cell papillary $\mathrm{RCC}^{13}$ were excluded. To diagnose MCRCC, we applied strict criteria based 

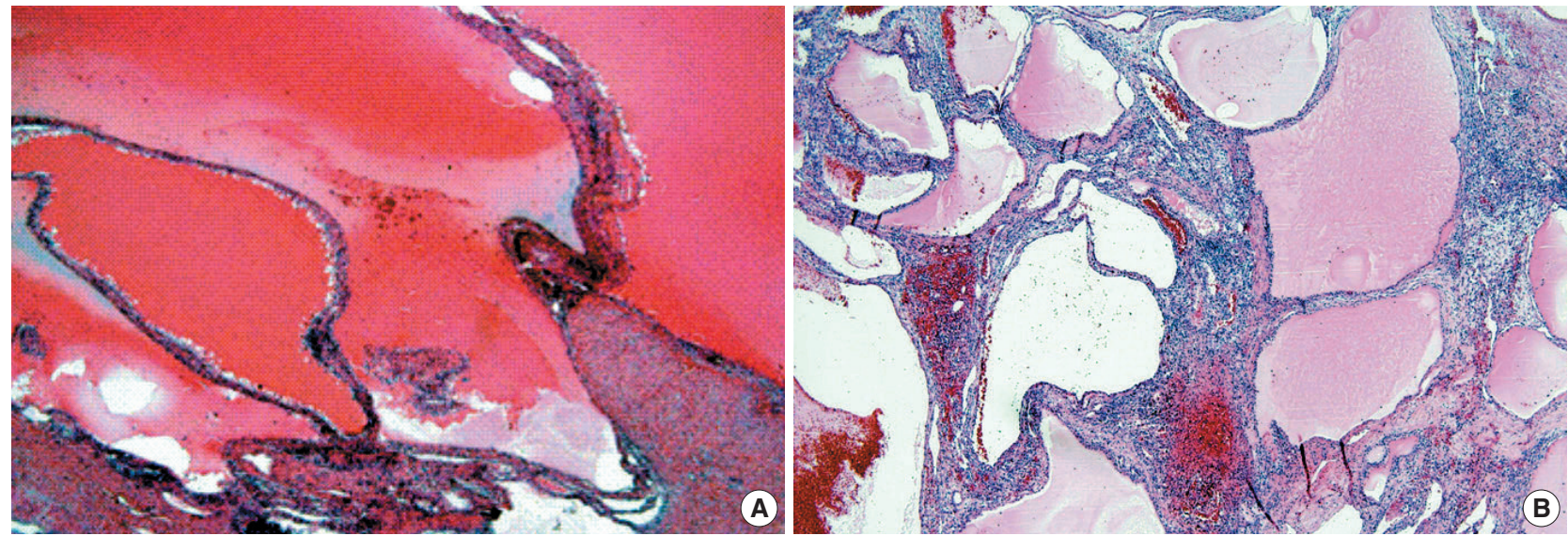

Fig. 1. Histologic appearance of cystic change in clear cell renal cell carcinoma compared to multilocular cystic renal cell carcinoma. (A) A multilocular cystic renal cell carcinoma excluded from this study. (B) Clear cell renal cell carcinoma with cystic change. Usually, the cystic area appears as macrocysts in a multilocular pattern. The lumen contains serous fluid and erythrocytes, but not necrotic tissue. There is expansile tumor mass in the cyst walls.

on the 2004 World Health Organization (WHO) classification. ${ }^{14}$ MCRCC was defined as the tumor mass entirely composed of multilocular cysts lined by thin septa containing clear tumor cells, and with no expansile solid nodule (Fig. 1A). Finally, the cases of 225 patients with clear cell RCC were examined for analysis.

\section{Collection of clinicopathologic features}

The clinical features included age at the time of surgery, sex and clinical outcomes. The duration of follow-up was calculated from the date of nephrectomy to the date of cancer progression (i.e., distant metastases after nephrectomy for the primary tumor), death, or last follow-up. The pathologic features evaluated included tumor size, tumor, node, and metastasis (TNM) stage according to the 2002 American Joint Committee on Cancer (AJCC) ${ }^{15}$ regional lymph node involvement, distant metastases, nuclear grade according to the Fuhrman system, and cystic change. If no pathologic confirmation of metastatic disease was performed, patients were assessed for clinical metastatic stage on the basis of clinical examination and radiologic studies. Tumor size was measured according to the longest diameter. Nuclear grade was based on the highest-grade tumor area identified. A tumor was regarded as having cystic change when it was grossly cystic and the cyst walls were lined by clear tumor cells. Cysts were either multilocular or unilocular and there was at least one area of expansile tumor nodule, which differentiated the tumor from MCRCC. In addition, the cysts could not contain necrotic tumor tissue. Usually, the cystic area consisted of macrocysts in a multilocular pattern with the lumens containing serous fluid and erythrocytes (Fig. 1B). Microscopic slides from all specimens were reviewed by two pathologists without knowledge of patient outcomes.

\section{Statistical methods}

Comparisons of clinical and pathologic features between clear cell RCC patients with and without cystic change were assessed using chi-square and Fisher exact tests. CSS was measured from the date of surgery to the date of cancer-related death or the last follow-up. Progression-free survival (PFS) was calculated from the date of surgery to the date of tumor recurrence/metastasis or the last follow-up. Survival analysis was performed using the Kaplan-Meier method and the results were compared by the logrank test. Multivariate analysis was performed using Cox proportional hazards regression models. Statistical analyses were performed using the SPSS ver. 17.0 (SPSS Inc., Chicago, IL, USA). All p-values of 0.05 or less were considered statistically significant.

\section{RESULTS}

The clinical and pathologic features for the 225 patients who underwent nephrectomy for clear cell RCC are summarized in Table 1 . The mean age at the time of surgery was 55 years (range, 28 to 82 years). The mean duration of follow-up was 59.96 months (median, 64.0 months; range, 2 to 97 months). Of the 225 patients, 45 (20\%) patients died during the follow-up, with $33(14.7 \%)$ dead of disease. One hundred and sixty-three 
Table 1. Clinicopathologic features of 225 patients who underwent nephrectomy for clear cell renal cell carcinoma

\begin{tabular}{|c|c|c|c|}
\hline Features & & Value & $\%$ \\
\hline \multicolumn{4}{|c|}{ Age at the time of surgery $(y r)$} \\
\hline & Mean \pm SD & $55.0 \pm 11.2$ & \\
\hline & Median & 55 & \\
\hline & Range & $28-82$ & \\
\hline \multicolumn{4}{|c|}{ Tumor size (cm) } \\
\hline & Mean \pm SD & $5.1 \pm 3.1$ & \\
\hline & Median & 4 & \\
\hline & Range & $1-16$ & \\
\hline \multicolumn{4}{|l|}{ Sex } \\
\hline & Female & 54 & 24 \\
\hline & Male & 171 & 76 \\
\hline \multicolumn{4}{|c|}{ Age category (yr) } \\
\hline & $<55$ & 116 & 51.5 \\
\hline & $\geq 55$ & 109 & 48.5 \\
\hline \multicolumn{4}{|c|}{ Tumor size $(\mathrm{cm})$} \\
\hline & $\leq 4$ & 114 & 50.7 \\
\hline & $>4$ & 111 & 49.3 \\
\hline \multicolumn{4}{|c|}{ Primary tumor status ${ }^{\mathrm{a}}$} \\
\hline & pT1 & 158 & 70.2 \\
\hline & pT2 & 28 & 12.4 \\
\hline & рT3 & 38 & 16.9 \\
\hline & pT4 & 1 & 0.4 \\
\hline \multicolumn{4}{|c|}{ Regional lymph nodes status ${ }^{a}$} \\
\hline & NO & 221 & 98.2 \\
\hline & $\mathrm{N} 1, \mathrm{~N} 2$ & 4 & 1.8 \\
\hline \multicolumn{4}{|c|}{ Distant metastasis ${ }^{a}$} \\
\hline & MO & 205 & 91.1 \\
\hline & M1 & 20 & 8.9 \\
\hline \multicolumn{4}{|c|}{ TNM stage ${ }^{a}$} \\
\hline & I & 155 & 68.9 \\
\hline & $\|$ & 22 & 9.8 \\
\hline & III & 26 & 11.6 \\
\hline & IV & 22 & 9.8 \\
\hline \multicolumn{4}{|c|}{ Fuhrman nuclear grade } \\
\hline & 1 & 22 & 9.8 \\
\hline & 2 & 104 & 46.2 \\
\hline & 3 & 76 & 33.8 \\
\hline & 4 & 23 & 10.2 \\
\hline \multicolumn{4}{|c|}{ Cystic change } \\
\hline & Absent & 159 & 70.7 \\
\hline & Present & 66 & 29.3 \\
\hline
\end{tabular}

${ }^{a}$ According to American Joint Committee on Cancer TNM staging system. $^{15}$

SD, standard deviation; TNM, tumor, node, and metastasis.

$(72.4 \%)$ patients were alive without evidence of RCC, and 17 (7.6\%) patients were currently alive with evidence of disease. Grossly, the mean tumor size was $5.1 \mathrm{~cm}$ (range, 1 to $16 \mathrm{~cm}$ ). One hundred and eleven (49.3\%) patients had tumor masses greater than $4 \mathrm{~cm}$ in size.

Cystic change in clear cell RCC was observed in 66 (29.3\%) patients (Table 1). Its associations with clinicopathologic features are summarized in Table 2. It was significantly associated with
Table 2. Relationship of the presence of cystic change within clear cell renal cell carcinoma to clinicopathologic features

\begin{tabular}{|c|c|c|c|}
\hline \multirow{2}{*}{$\begin{array}{l}\text { Clinicopathologic } \\
\text { features }\end{array}$} & \multicolumn{2}{|c|}{ Cystic change } & \multirow[b]{2}{*}{ p-value } \\
\hline & $\begin{array}{c}\text { Absent } \\
\mathrm{n}(\%)\end{array}$ & $\begin{array}{c}\text { Present } \\
n(\%)\end{array}$ & \\
\hline Sex & & & 0.188 \\
\hline Female & $42(26.4)$ & $12(18.2)$ & \\
\hline Male & $117(73.6)$ & $54(81.8)$ & \\
\hline Age (yr) & & & $<0.001$ \\
\hline$<55$ & $70(44.0)$ & $46(69.7)$ & \\
\hline$\geq 55$ & $89(56.0)$ & $20(30.3)$ & \\
\hline Tumor size $(\mathrm{cm})$ & & & 0.029 \\
\hline$\leq 4$ & $73(45.9)$ & $41(62.1)$ & \\
\hline$>4$ & $86(54.1)$ & $25(37.9)$ & \\
\hline Primary tumor status ${ }^{a}$ & & & 0.035 \\
\hline pT1, T2 & $126(79.2)$ & $60(90.9)$ & \\
\hline $\mathrm{pT} 3, \mathrm{~T} 4$ & $33(20.8)$ & $6(9.1)$ & \\
\hline Regional lymph nodes status ${ }^{a}$ & & & 0.19 \\
\hline NO & $155(97.5)$ & $66(100)$ & \\
\hline $\mathrm{N} 1, \mathrm{~N} 2$ & $4(2.5)$ & 0 & \\
\hline Distant metastasis ${ }^{\mathrm{a}}$ & & & 0.04 \\
\hline MO & $141(88.7)$ & $64(97.0)$ & \\
\hline M1 & $18(11.3)$ & $2(3.0)$ & \\
\hline TNM stage ${ }^{a}$ & & & 0.011 \\
\hline | and || & $118(74.2)$ & $59(89.4)$ & \\
\hline III and IV & $41(25.8)$ & $7(10.6)$ & \\
\hline Fuhrman nuclear grade & & & 0.038 \\
\hline 1 and 2 & $82(51.6)$ & $44(66.7)$ & \\
\hline 3 and 4 & $77(48.4)$ & $22(33.3)$ & \\
\hline
\end{tabular}

${ }^{a}$ According to American Joint Committee on Cancer TNM staging system. ${ }^{15}$

TNM, tumor, node, and metastasis.

patient age less than 55 years old ( $\mathrm{p}<0.001$ ), tumor size $4 \mathrm{~cm}$ or less $(\mathrm{p}=0.029)$, less advanced primary tumor status $(\mathrm{p}=0.035)$, absence of distant metastases at initial diagnosis $(\mathrm{p}=0.04)$, lower TNM stage $(\mathrm{p}=0.011)$, and lower Fuhrman nuclear grade $(\mathrm{p}=$ 0.038) (Table 2).

Univariate analysis showed that patients with age younger than 55 years old (CSS, $\mathrm{p}=0.001 ; \mathrm{PFS}, \mathrm{p}<0.001)$, tumor size 4 $\mathrm{cm}$ or less $(\mathrm{p}<0.001)$, less advanced primary tumor status $(\mathrm{p}<$ $0.001)$, absence of regional lymph node ( $\mathrm{p}<0.001)$, abscence of distant metastasis $(\mathrm{p}<0.001)$, lower TNM stage $(\mathrm{p}<0.001)$, and lower Fuhrman nuclear grade $(\mathrm{p}<0.001)$ were significantly associated with longer CSS and PFS (Table 3). Tumors with cystic change were also correlated with longer survival (CSS, $\mathrm{p}=0.015$; PFS, $\mathrm{p}=0.004)$ (Fig. 2).

Multivariate analysis determined the following independent prognostic factors for CSS as well as for PFS in this study, as follows: tumor size $4 \mathrm{~cm}$ or less (CSS, $\mathrm{p}=0.032 ; \mathrm{PFS}, \mathrm{p}=0.002$ ), primary tumor status (CSS, $\mathrm{p}=0.005 ; \mathrm{PFS}, \mathrm{p}=0.005)$, regional lymph node status (CSS, $\mathrm{p}=0.037$; PFS, $\mathrm{p}=0.013$ ), distant 
metastasis (both CSS and PFS, $\mathrm{p}<0.001$ ), and Fuhrman nuclear grade $(\mathrm{CSS}, \mathrm{p}=0.013 ; \mathrm{PFS}, \mathrm{p}=0.008)($ Table 4$)$. Although cys-

Table 3. Univariate analysis of clinicopathologic factors in 225 patients with clear cell renal cell carcinoma

\begin{tabular}{lcc}
\hline $\begin{array}{l}\text { Clinicopathologic } \\
\text { features }\end{array}$ & $\begin{array}{c}\text { Cancer specific } \\
\text { survival p-value }\end{array}$ & $\begin{array}{c}\text { Progression free } \\
\text { survival p-value }\end{array}$ \\
\hline Age $(\mathrm{yr})<55$ vs $\geq 55$ & 0.001 & $<0.001$ \\
Tumor size $(\mathrm{cm}) \leq 4$ vs $>4$ & $<0.001$ & $<0.001$ \\
pT1, pT2 vs pT3, pT4 & $<0.001$ & $<0.001$ \\
pN0 vs pN1, pN2 & $<0.001$ & $<0.001$ \\
pM0 vs pM1 & $<0.001$ & $<0.001$ \\
Stage I, II vs III, IV & $<0.001$ & $<0.001$ \\
Nuclear grade 1, 2 vs 3, 4 & $<0.001$ & $<0.001$ \\
Cystic change absent vs present & 0.015 & 0.004 \\
\hline
\end{tabular}

tic change did not retain prognostic significance for cancer-related death by multivariate analysis, it significantly decreased the risk of cancer progression regardless of other clinicopathologic parameters (risk ratio $[\mathrm{RR}], 0.27$; $95 \%$ confidence interval [CI], 0.11 to $0.69 ; \mathrm{p}=0.006$ ).

\section{DISCUSSION}

Imaging studies reveal cystic changes in $4 \%$ to $15 \%$ of renal cell carcinomas. ${ }^{16}$ In 1986, Hartman et al..$^{16}$ divided these tumors into 4 groups to explain their cystic nature: intrinsic multilocular growth, intrinsic unilocular growth, cystic necrosis, and origin from the epithelial lining of a pre-existing cyst. Several

Table 4. Multivariate analysis for cancer-specific and progression-free survival

\begin{tabular}{|c|c|c|c|c|}
\hline \multirow{2}{*}{ Feature } & \multicolumn{2}{|c|}{ Cancer-specific survival } & \multicolumn{2}{|c|}{ Progression-free survival } \\
\hline & $\mathrm{RR}(95 \% \mathrm{Cl})$ & $\mathrm{p}$-value & $\mathrm{RR}(95 \% \mathrm{Cl})$ & p-value \\
\hline Age $(y r)<55$ vs $\geq 55$ & $0.65(0.26-1.61)$ & 0.35 & $1.06(0.54-2.10)$ & 0.865 \\
\hline Tumor size $(\mathrm{cm}) \leq 4$ vs $>4$ & $9.53(1.21-74.90)$ & 0.032 & $5.57(1.89-16.42)$ & 0.002 \\
\hline pT1, T2 vs pT2, T3 & $2.98(1.40-6.35)$ & 0.005 & $2.46(1.31-4.61)$ & 0.005 \\
\hline No vs N1, N2 & $3.69(1.08-12.55)$ & 0.037 & $5.55(1.44-21.41)$ & 0.013 \\
\hline M0 vs M1 & $11.08(4.95-24.80)$ & $<0.001$ & $13.63(5.99-31.00)$ & $<0.001$ \\
\hline Nuclear grade 1, 2 vs 3, 4 & $3.97(1.34-11.78)$ & 0.013 & $2.85(1.32-6.15)$ & 0.008 \\
\hline Cystic change absent vs present & $0.34(0.11-1.04)$ & 0.058 & $0.27(0.11-0.69)$ & 0.006 \\
\hline
\end{tabular}

$\mathrm{RR}$, risk ratio; $95 \% \mathrm{Cl}, 95 \%$ confidence interval.
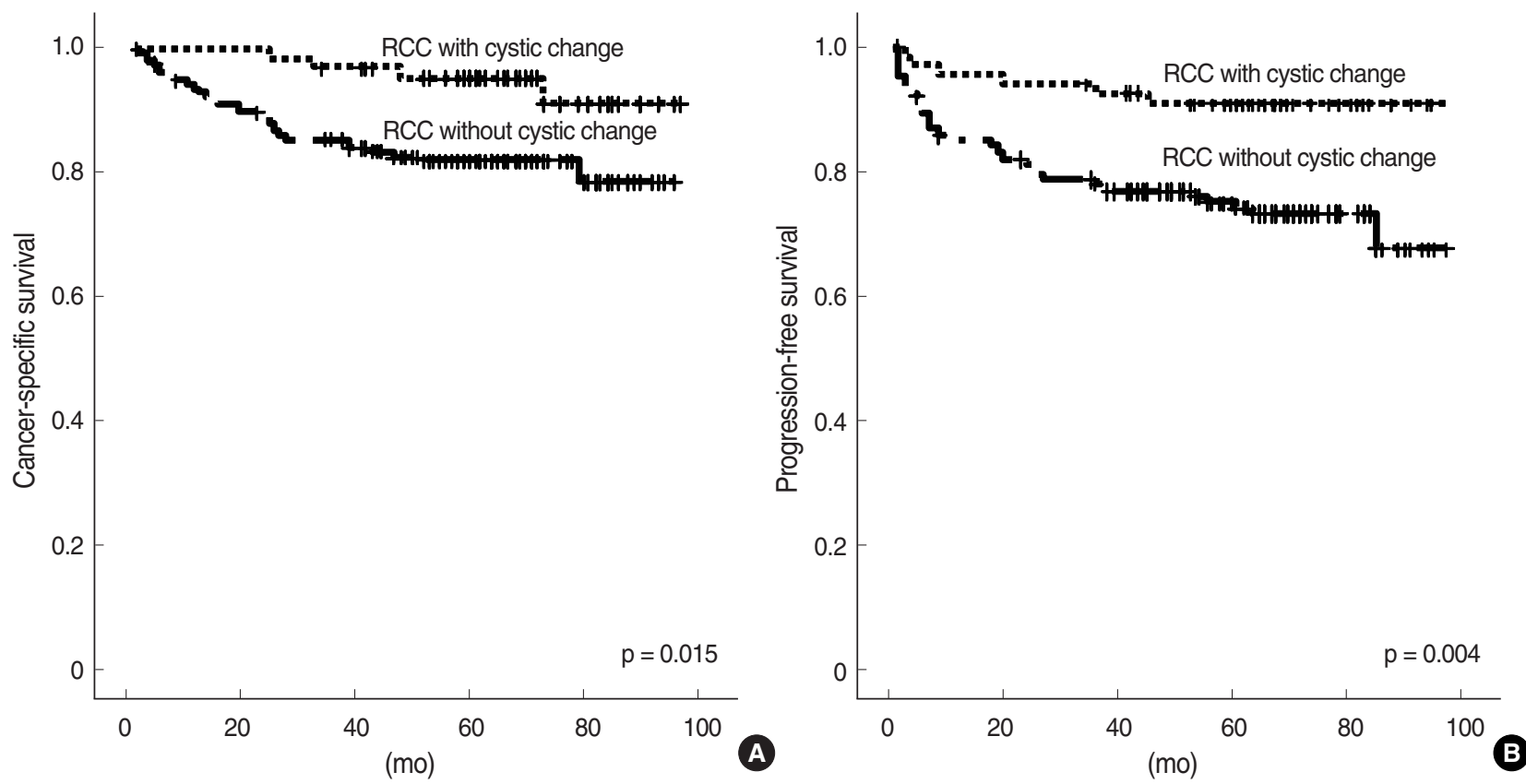

Fig. 2. Kaplan-Meier survival curves according to the presence of cystic change in 225 patients with clear cell renal cell carcinoma (RCC). (A) Cancer-specific survival (log-rank test for trend, $p=0.015$ ). (B) Progression-free survival (log rank test for trend, $p=0.004$ ). 
authors have reported that such "cystic RCC" had a more favorable prognosis than noncystic RCC. ${ }^{7-11}$ Bielsa et al. and Webster et al. ${ }^{11}$ demonstrated that survival was significantly longer in patients with cystic RCC. In these studies, some cases of cystic RCC with multilocular growth pattern might now be categorized as multilocular cystic RCC by the 2004 WHO classification of the renal tumors. ${ }^{14}$ MCRCC is composed entirely of cysts of varying sizes lined by a single layer of neoplastic cells and without an expansile tumor nodule. It must be distinguished from conventional RCC with cystic change, since it has an extremely good prognosis ${ }^{5}$ and currently is considered as a specific entity, "multilocular cystic renal neoplasm of low malignant potential". ${ }^{17}$ Consequently, those previous studies may have overestimated the prognosis of patients with cystic RCC. Furthermore, some studies also included RCC with cystic necrosis and this could act as a confounding factor contributing to the underestimation of clinical outcome. Consequently, we excluded cases of MCRCC in the current study and did not consider areas of cystic necrosis as cystic change. This is the first study that statistically evaluated the prognostic impact of cystic change in clear cell RCC excluding cases with MCRCC and RCC with cystic necrosis.

The TNM staging system is the most studied and most accurate tool for predicting the prognosis of RCC. ${ }^{18}$ Our study was in close agreement with the results of previous studies in spite of the relatively small population size. Because the outcomes of RCC can still be unpredictable, other prognostic factors and outcome prediction models have been studied. The current version of the TNM staging system uses a $4 \mathrm{~cm}$ cut-off value to distinguish between T1a and T1b RCC. Several authors have suggested different tumor size cut-off ranging from $4.5 \mathrm{~cm}$ to $5.5 \mathrm{~cm}^{19}$ In this study, we adopted $4 \mathrm{~cm}$ as a tumor size breakpoint for stratifying the patients and showed that tumor sizes greater than $4 \mathrm{~cm}$ significantly increased the risk of cancer mortality (RR, 9.53; 95\% CI, 1.21 to 74.90; $\mathrm{p}=0.032$ ) and progression (RR, $5.57 ; 95 \% \mathrm{CI}, 1.89$ to $16.42 ; \mathrm{p}=0.002$ ) by multivariate analysis. Fuhrman nuclear grade has been shown to be of prognostic significance in series of mixed tumor types. ${ }^{3,20,21}$ However, using 4-tiered system, it did not retain prognostic significance by multivariate analysis that included TNM stage..$^{20}$ On the other hand, significant differences in outcome were seen after separating patients with nuclear grade 1 and grade 2 tumors from patients with grade 3 and grade 4 tumors. ${ }^{22}$ Our study also showed that nuclear grade maintained prognostic significance only after grouping patients into 2-tiered system (grade 1 and 2 vs grade 3 and 4). We demonstrated that cystic change in clear cell RCC was significantly associated with patient age younger than 55 years old and less aggressive properties as follows: tumor size 4 $\mathrm{cm}$ or less, less advanced primary tumor status, absence of distant metastases at initial diagnosis, lower TNM stage, and lower Fuhrman nuclear grade. By univariate analysis, cystic change was significantly associated with longer survival (CSS, $p=0.015)$ and less intensive disease progression (PFS, $\mathrm{p}=0.004)$. After adjustment for tumor size, primary tumor status, regional lymph node status, distant metastasis, and Fuhrman nuclear grade, clear cell RCC with cystic change exhibited a significantly decreased likelihood of cancer progression ( $R R, 0.27 ; \mathrm{p}=0.006$ ). Therefore, the presence of cystic architecture in clear cell RCC, when grossly detected and then microscopically confirmed, is a good independent predictor for cancer progression, even if the cystic portion is not large enough to diagnose multilocular cystic RCC. Additional studies with large population size are needed to clarify the definition of cystic change and to better understand its impact on cancer mortality.

In conclusion, clear cell RCC with cystic change was found to be significantly associated with more favorable clinicopathologic parameters than noncystic RCC. In addition, the presence of cystic architecture in clear cell RCC was identified as an independent predictor of PFS by multivariate analysis. Routine documentation of cystic change may be advisable during the pathologic assessment of RCC.

\section{REFERENCES}

1. Jemal A, Siegel R, Ward E, Hao Y, Xu J, Thun MJ. Cancer statistics, 2009. CA Cancer J Clin 2009; 59: 225-49.

2. Lynch CF, Cohen MB. Urinary system. Cancer 1995; 75: 316-29.

3. Cheville JC, Lohse CM, Zincke H, Weaver AL, Blute ML. Comparisons of outcome and prognostic features among histologic subtypes of renal cell carcinoma. Am J Surg Pathol 2003; 27: 612-24.

4. Imura J, Ichikawa K, Takeda J, et al. Multilocular cystic renal cell carcinoma: a clinicopathological, immuno- and lectin histochemical study of nine cases. APMIS 2004; 112: 183-91.

5. Suzigan S, López-Beltrán A, Montironi R, et al. Multilocular cystic renal cell carcinoma: a report of 45 cases of a kidney tumor of low malignant potential. Am J Clin Pathol 2006; 125: 217-22.

6. Gong K, Zhang N, He Z, Zhou L, Lin G, Na Y. Multilocular cystic renal cell carcinoma: an experience of clinical management for 31 cases. J Cancer Res Clin Oncol 2008; 134: 433-7.

7. Bielsa O, Lloreta J, Gelabert-Mas A. Cystic renal cell carcinoma: pathological features, survival and implications for treatment. Br J 
Urol 1998; 82: 16-20.

8. Corica FA, Iczkowski KA, Cheng L, et al. Cystic renal cell carcinoma is cured by resection: a study of 24 cases with long-term followup. J Urol 1999; 161: 408-11.

9. Nassir A, Jollimore J, Gupta R, Bell D, Norman R. Multilocular cystic renal cell carcinoma: a series of 12 cases and review of the literature. Urology 2002; 60: 421-7.

10. Han KR, Janzen NK, McWhorter VC, et al. Cystic renal cell carcinoma: biology and clinical behavior. Urol Oncol 2004; 22: 410-4.

11. Webster WS, Thompson RH, Cheville JC, Lohse CM, Blute ML, Leibovich BC. Surgical resection provides excellent outcomes for patients with cystic clear cell renal cell carcinoma. Urology 2007; 70: 900-4.

12. Frank I, Blute ML, Cheville JC, Lohse CM, Weaver AL, Zincke H. An outcome prediction model for patients with clear cell renal cell carcinoma treated with radical nephrectomy based on tumor stage, size, grade and necrosis: the SSIGN score. J Urol 2002; 168: 2395400.

13. Gobbo S, Eble JN, Grignon DJ, et al. Clear cell papillary renal cell carcinoma: a distinct histopathologic and molecular genetic entity. Am J Surg Pathol 2008; 32: 1239-45.

14. Lopez-Beltran A, Scarpelli M, Montironi R, Kirkali Z. 2004 WHO classification of the renal tumors of the adults. Eur Urol 2006; 49:
798-805.

15. Greene FL, Page DL, Fleming ID, et al. AJCC cancer staging manual. 6th ed. New York: Springer-Verlag, 2002.

16. Hartman DS, Davis CJ Jr, Johns T, Goldman SM. Cystic renal cell carcinoma. Urology 1986; 28: 145-53.

17. Lopez-Beltran A, Carrasco JC, Cheng L, Scarpelli M, Kirkali Z, Montironi R. 2009 update on the classification of renal epithelial tumors in adults. Int J Urol 2009; 16: 432-43.

18. Frank I, Blute ML, Leibovich BC, Cheville JC, Lohse CM, Zincke H. Independent validation of the 2002 American Joint Committee on cancer primary tumor classification for renal cell carcinoma using a large, single institution cohort. J Urol 2005; 173: 1889-92.

19. Ficarra V, Novara G, Galfano A, Artibani W. Neoplasm staging and organ-confined renal cell carcinoma: a systematic review. Eur Urol 2004; 46: 559-64.

20. Kim H, Cho NH, Kim DS, et al. Renal cell carcinoma in South Korea: a multicenter study. Hum Pathol 2004; 35: 1556-63.

21. Patard JJ, Leray E, Rioux-Leclercq N, et al. Prognostic value of histologic subtypes in renal cell carcinoma: a multicenter experience. J Clin Oncol 2005; 23: 2763-71.

22. Usubütün A, Uygur MC, Ayhan A, et al. Comparison of grading systems for estimating the prognosis of renal cell carcinoma. Int Urol Nephrol 1998; 30: 391-7. 